\title{
Lead Levels in the Bones of Small Rodents from Alpine and Subalpine Habitats in the Tian-Shan Mountains, Kyrgyzstan
}

\author{
Zuzana Ballová * (D) and Marián Janiga \\ Institute of High Mountain Biology, University of Žilina, Tatranská Javorina 7, 05956 Žilina, Slovakia; \\ janiga@uniza.sk \\ * Correspondence: zuzana.ballova@uniza.sk; Tel.: +42-152-449-9108
}

Received: 23 November 2017; Accepted: 20 January 2018; Published: 23 January 2018

\begin{abstract}
High mountain areas are an appropriate indicator of anthropogenic lead (Pb), which can reach remote mountain ranges through long distance atmospheric transport. We compared the content of $\mathrm{Pb}$ in ecologically equivalent rodent species from Tian-Shan with European mountain ranges including the Tatra, Vitosha and Rila mountains. We used bone tissues from terminal tail vertebrae of small rodents for detection of $\mathrm{Pb}$ levels through electro-thermal atomic absorption spectroscopy (AAS). The tailbones of Tian-Shan rodents had significantly lower Pb levels than snow voles from the Tatra Mountains, but there was no significant difference in comparison with the Vitosha and Rila mountains. We can conclude that Tian-Shan shows lower pollution by $\mathrm{Pb}$ than the Tatras, which may be a result of prolonged industrialization of north-western Europe and strongly prevailing west winds in this region.
\end{abstract}

Keywords: lead pollution; alpine environments; Alticola argentatus; Microtus gregalis; atmospheric deposition; heavy metals

\section{Introduction}

Atmospheric lead $(\mathrm{Pb})$ fluctuations are dominated by anthropogenic sources. Even in areas far removed from industrial emission sources, $\mathrm{Pb}$ concentrations in the surface soil layers are far above their natural concentration range [1]. Anthropogenic $\mathrm{Pb}$ could therefore reach more remote high mountains through long distance atmospheric transport [2].

Mountains are amongst the most fragile environments in the world [3]. Many studies have shown that Tian-Shan is one of the mountain ranges in central Asia with the largest anthropogenic sources of heavy metals [4-8]. $\mathrm{Pb}, \mathrm{Cd}$ and $\mathrm{Cu}$ concentrations from the Inilchek ice core (central Tian-Shan) reflect declines during the 1980s concurrent with Soviet economic declines, however, due to the rapid industrial and agricultural growth of western $\mathrm{China}, \mathrm{Pb}, \mathrm{Cd}$ and $\mathrm{Cu}$ trends increased during the 1990s [4]. Lead levels rise with altitude in soils, grass and moss tissues. In mosses, relatively high amounts of lead were found, reflecting the atmospheric lead pollution in the Kyrgyz Tian-Shan mountains [9]. Šefrna et al. [10] found that $\mathrm{Pb}$ in soils from two altitudinal transects in the northern and the central Tian-Shan was slightly above the world average in almost all locations. In Kazakhstan, the soils on the northern slopes of Dzungarian Alatau contained from 20 to $30 \mathrm{ppm}$ of lead, exceeding the values of the maximum concentration limit [11]. Demand for energy continues to rise in Asia and increased use of fossil fuels threatens to accelerate climate change as well as metal pollution. Little attention has been paid to the synergistic or antagonistic effects of lead with the specific impacts of global warming. Global warming is connected not only to the increase in temperature of the air and intensity of thawing of ice but also to desertification of territories adjoining Tian-Shan. Effects of increased temperature and lead deposition may influence many 
biological processes including: distribution and concentration of lead within the bodies of different organisms; changed seasonality of lead poisoning; lead tolerance by plants and animals; inhibition of heme-biosynthesis in vertebrates; increased sensibility of nervous systems; decreased availability of essential elements (e.g., $\mathrm{Ca}$ ); and change and decline in biodiversity in sensitive regions such as alpine habitats [12]. One of the negative effects of desertification is the increase of dust in the atmosphere and its subsidence on glaciers [13]. The influence of anthropogenous factors leads to impurity of glaciers and mountain water sources. Water source pollution primarily stems from the mining and mineral processing industries. Annual accumulation of waste makes up 25 million $\mathrm{m}^{3}, 42$ million tons of tailings and 300 thousand tons of metallurgical slag. Their presence in the Tian-Shan environment leads to the pollution of air and soil with lead, zinc, arsenic, cadmium, sulphur oxides and nitrogen or cyanides [14].

It is generally known that small terrestrial mammals are the most suitable bio-monitors of heavy-metal pollution to apply findings to humans [15]. In Tian-Shan, the silver mountain vole (Alticola argentatus) and narrow-headed vole (Microtus gregalis) are some of the most widespread rodents. The silver mountain vole is ecologically equivalent to the snow vole (Chionomys nivalis), which is commonly distributed in European high mountains. A. argentatus, similarly to C. nivalis, prefer rocky alpine habitats, and breed twice per year up to $3800 \mathrm{~m}$ a.s.l. [16,17]. The species diet consists primarily of small roots, leaves, seeds and flowers $[17,18]$. The species $M$. gregalis has a large population size and a wide distribution. It inhabits altitudes up to $4000 \mathrm{~m}$, including tundra, plains and mountain steppes and meadows. This species lives in high mountains similarly to A. argentatus and $C$. nivalis. Narrow-headed voles feed on various wild and cultivated plants, but tend to prefer legumes. Their reproductive period lasts throughout the warmer months of the year; in tundra zones reproduction often starts under snow cover. The species has up to 4 litters in mountains and northern areas [19]. The silver mountain vole is on The IUCN Red List of Threatened Species under "Least Concern" in view of its wide distribution, presumed large population, and because it is unlikely to be declining fast enough to qualify for listing in a more threatened category. This widely distributed species has been recorded from the mountainous areas of Central Asia (eastern Kazakhstan, Uzbekistan, Kyrgyzstan and Tajikistan), western China (northern Xinjiang and Gansu), northern Afghanistan, North West Frontier Province in Pakistan and Jammu and Kashmir [20].

In our previous study, we confirmed that the Carpathians are still one of the most polluted mountain ranges in Europe [21]. We decided to compare the lead pollution in the West Carpathians (Tatra mountains) and Vitosha and Rila mountains (Bulgaria) in Europe with one of the most polluted mountain ranges in central Asia-the Tian-Shan mountains. We hypothesized that the Tian-Shan would be more lead polluted than European mountains as is indicated by several studies on Tian-Shan pollution with heavy metals. We also predicted that the silver mountain vole and narrow-headed vole from Tian-Shan are ecologically equivalent rodent species to snow voles from European mountain ranges and are suitable indicators of lead in high mountain environments. The aim of our study was to investigate $\mathrm{Pb}$ levels in mountain rodents from Tian-Shan and compare the results with equivalent rodent species from European mountain ranges.

\section{Experiments}

\subsection{Sample Collection}

To compare the lead levels in the bones of rodents, two of the most abundant species of rodents in Tian-Shan, A. argentatus and M. gregalis were studied. Both species live up to $4000 \mathrm{~m}$ a.s.l. and they are very common in the high mountains. Rodents were trapped at the following locations during the year 2012: A. argentatus: Ala Archa $\left(\mathrm{N} 42^{\circ} 31^{\prime} 52.9^{\prime \prime}, \mathrm{E}^{\circ} 4^{\circ} 31^{\prime} 29.7^{\prime \prime}\right)-5$ specimens, 9 September, and Besh Tash $\left(\mathrm{N} 42^{\circ} 10^{\prime} 24.6^{\prime \prime}, \mathrm{E} 72^{\circ} 32^{\prime} 37.2^{\prime \prime}\right)$-1 specimen, 20 August; Besh Tash (N42 ${ }^{\circ} 2^{\prime} 37.4^{\prime \prime}$, E72 $\left.28^{\prime} 57.4^{\prime \prime}\right)$-1 specimen, 20 June; and Ala Bel $\left(\mathrm{N} 42^{\circ} 12^{\prime} 13.3^{\prime \prime}, \mathrm{E}^{\circ} 03^{\circ} 41.4^{\prime \prime}\right)$-1 specimen, 21 August and M. gregalis: Suyak Pass $\left(\mathrm{N} 41^{\circ} 48^{\prime} 16.8^{\prime \prime}\right.$, E77 $\left.{ }^{\circ} 45^{\prime} 33.9^{\prime \prime}\right)$-3 specimens, 2 September. 
Sampling was performed during one-night live-trap periods at each site using 30 Sherman live traps baited with commercial seeds for rodents. The traps were divided into line transects and set up approximately $10 \mathrm{~m}$ apart from one another. The captured animals were identified at species level and terminal parts of their tails were clipped. Bone tissues from terminal tail vertebrae of small rodents were used for detection of $\mathrm{Pb}$ levels. The individuals were immediately released at the point of capture.

The snow voles were sampled from September to October 2009-2010 in Slovakia (High Tatras, Brestová and Biele plesá) and 2009 in Bulgaria (Rila, Vitosha). In the four monitoring fields in Slovakia and Bulgaria, Sherman traps baited with fresh apples and commercial seeds for rodents were divided into squares or lines and set up approximately $10 \mathrm{~m}$ apart from one another. Trapped individuals were determined and parts of their tails were also clipped. For details on sample collection see Janiga, Hrehová, Dimitrov, Gerasimova and Lovari [21].

\subsection{Detection of Lead Levels}

$\mathrm{Pb}$ content in all rodent tails was determined by using electro-thermal atomic absorption spectroscopy (AAS Perkin Elmer 1100B, Norwalk, CT, USA). The device was equipped with deuterium background correction and an HGA 700 graphite furnace with an automated sampler AS-70 and worked under the following conditions: wavelength $283.3 \mathrm{~nm}$; slit $0.7 \mathrm{~nm}$; lamp current $10 \mathrm{~mA}$. We programed the temperature as follows: Drying 1: 70/10/10; Drying 2:150/2/60; Pyrolysis: 800/15/30; Atomization: 1800/0/3; Cleaning: 2500/0/3 (temperature $\left({ }^{\circ} \mathrm{C}\right) / \mathrm{ramp}$ time $(\mathrm{s}) / \mathrm{hold}$ time (s)).

To prepare calibration solutions, a certified stock standard solution $1000 \mathrm{mg} / \mathrm{L}$ of $\mathrm{Pb}$ (Merck, Darmstadt, Germany) and the calibration range 5-20 $\mu \mathrm{g} / \mathrm{L}$ were used. We applied $\mathrm{NH}_{4} \mathrm{H}_{2} \mathrm{PO}_{4}(0.2 \mathrm{mg})$ as a matrix modifier during $\mathrm{Pb}$ determination.

The results were evaluated from the calibration curve and the accuracy of the determination was proven by the standard addition technique. Results of the three additions were accepted only when the linear regression equation had a fit of at least 0.99 . The Pb detection limit was $0.5 \mu \mathrm{g} / \mathrm{kg}$. Procedural blanks and calibration standards were taken through digestion and storage procedures to evaluate contamination from reagents and containers. The method precision was better than $<5 \%$ (RSD).

The accuracy of the method was established by analysing of the reference material Bovine Liver No. 12-2-01 (Slovak Metrological Institute). The determined value $(0.70 \pm 0.05 \mathrm{mg} / \mathrm{kg})$ agreed well with the certified value $(0.71 \pm 0.08 \mathrm{mg} / \mathrm{kg})$, and within the uncertainty limit established for the material.

\subsection{Statistics}

The mean concentrations of $\mathrm{Pb}$ in rodent tail bone tissues were compared between different mountain ranges (Tatra, Vitosha and Rila, and Tian-Shan Mountains). For the comparison of $\mathrm{Pb}$ amounts between Tatra Mountains and Vitosha and Rila Mountains, our already published data from snow vole tails were used [21]. The $\mathrm{Pb}$ amounts among different groups were statistically compared using one way ANOVA and Fisher's Least Significant Difference (LSD) test at the 95\% confidence level $(p<0.05)$. The statistical analyses were performed with Statistica 12 software (Stat Soft CR, Prague, Czech Republic) for Windows.

\section{Results}

Rodents from Tian-Shan had relatively variable levels of $\mathrm{Pb}$ content in the tail vertebrae. The highest values seem to be from National Park Ala Archa, located not far from Bishkek, the capital of Kyrgyzstan (Table 1). Lead levels in tail vertebrae were significantly higher in the voles from the West Carpathians than from the Tian Shan mountains or from Bulgarian mountains, Rila and Vitosha (Figure 1). 
Table 1. Pb contents in two vole species from Tien-Shan obtained by using electro-thermal atomic absorption spectroscopy.

\begin{tabular}{cccc}
\hline Date & Species & Location & $\mathbf{P b}[\boldsymbol{\mu g} / \mathbf{g}]^{\mathbf{1}}$ \\
\hline 11 September 2012 & Alticola argentatus & Ala Archa & $2.94 \pm 0.12$ \\
11 September 2012 & Alticola argentatus & Ala Archa & $2.54 \pm 0.14$ \\
11 September 2012 & Alticola argentatus & Ala Archa & $5.59 \pm 0.11$ \\
11 September 2012 & Alticola argentatus & Ala Archa & $10.7 \pm 0.38$ \\
11 September 2012 & Alticola argentatus & Ala Archa & $11.1 \pm 0.28$ \\
22 August 2012 & Alticola argentatus & Besh Tash & $4.21 \pm 0.14$ \\
2 September 2012 & Microtus gregalis & Suyak Pass & $1.18 \pm 0.18$ \\
2 September 2012 & Microtus gregalis & Suyak Pass & $3.46 \pm 0.12$ \\
2 September 2012 & Microtus gregalis & Suyak Pass & $4.67 \pm 0.25$ \\
23 August 2012 & Alticola argentatus & Ala Bel & $4.77 \pm 0.25$ \\
22 June 2012 & Alticola argentatus & Besh Tash & $2.07 \pm 0.11$ \\
\hline \multicolumn{4}{c}{ 1 pchar $=0.10 \mu \mathrm{g} / \mathrm{L}}$.
\end{tabular}

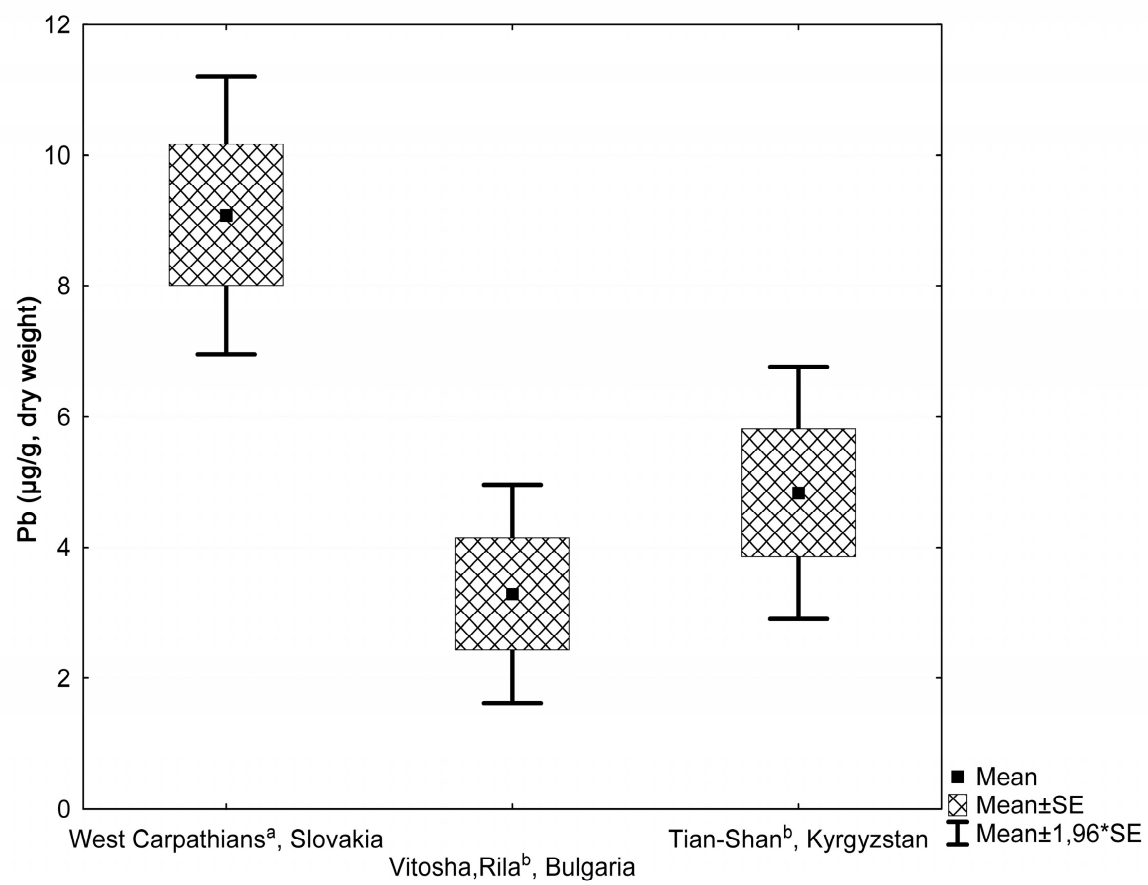

Figure 1. Mean lead concentrations ( $\mu \mathrm{g} / \mathrm{g}$ dry weight) in the tail vertebrae of voles from the Tatra, Vitosha and Rila mountains, and Tian-Shan mountains. Groups with different indices are significantly different at $p=0.05$ (One-way ANOVA, Fisher's LSD test).

\section{Discussion}

With the current rapid economic development in the Tian-Shan Mountains, anthropogenic sources are playing principal roles in serious heavy metal accumulations in this region. This problem warrants immediate and widespread attention to prevent further deterioration of the soil and water environments [7]. For example, analysis of samples from Miaoergou flat-topped glacier, eastern Tian-Shan, showed long-term variations of atmospheric transport and deposition of metals at high altitudes [8]. Contamination by heavy metals increased markedly, especially after the 2000s. Lake Sayram in central Chinese Tian-Shan was considered to be moderately polluted by $\mathrm{Cd}, \mathrm{Hg}$ and $\mathrm{Pb}$. Furthermore, the measurements of $206 \mathrm{~Pb} / 207 \mathrm{~Pb}$ ratios demonstrate that mining, coal burning emissions and $\mathrm{Pb}$ in vehicle gasoline were major sources of heavy metal pollution in the Tian-Shan region [5].

In alpine habitats, food chains via herbivores may carry considerable concentrations of lead. Many species respond quickly to various environmental changes and geographical differences in lead 
loadings. We found significant difference in the amount of lead in the voles from Tian-Shan and the West Carpathian mountains. Small mammals are top indicators of short-term lead pollution due to their small body size, high metabolic rate and short lifespan [22]. In contrast, large herbivores are more useful for biomonitoring of regional and long-termed differences in lead pollution [23]. During the completion of our research projects in Tian-Shan mountains, Hančinský [24] used field XRF spectrophotometry and compared the amount of lead in the bones of wild ruminants from Tian-Shan (Ovis ammon polli, Capra sibirica) to those from the West Carpathian mountains (Rupicapra rupicapra tatrica). He detected lead (above the measurement limit) in one of 38 Tian-Shan Ovis and Capra samples. Comparatively, in the Tatra chamois, 57 per cent of a total of 30 samples contained detectable lead. Results of lead levels in the bones of short-termed as well as long-termed herbivorous bio-indicators provide compelling evidence and support our previous findings [23] that the West Carpathians and mainly the High Tatra mountains represent a barrier for the atmospheric pollutants from the north-west part of Europe. In Slovakia, there are only a few local small polluters situated throughout the Tatras, and investigation shows that contamination by lead in mountain regions is caused by long-range transport. Thus, considerable attention must be paid to the West Carpathians, where the atmospheric lead loads are significantly higher than more polluted regions such as Tian-Shan or the Bulgarian Balkan mountains [25]. Our data from Suyak Pass was collected from a highly polluted valley used by the Kumtor company for transport of gold and other mineral resources. Kumtor is recognized as one of the most important environmental polluters in Kyrgyzstan [25]. In spite of this, voles from the valley showed lower bone concentrations of lead than voles from the Tatra mountains.

$\mathrm{Pb}$ concentrations steadily decline with increasing trophic levels, but the accumulation of heavy metals in specific animal organ tissues should not be neglected, though transfer of metals to animals from plants and insects is limited [26]. Exposure of wildlife to potentially toxic lead is of concern in instances where the availability of dietary $\mathrm{Ca}$ and $\mathrm{P}$ is low and the availability of lead is high. Depressed levels of $\mathrm{Ca}$ are particularly effective in increasing the uptake and toxicity of $\mathrm{Pb}$ in birds and mammals $[27,28]$. Valašková and Janiga [29] compared 21 element concentrations in the bones of domestic and wild ruminants from the Tian-Shan mountains and found that domestic animals accumulated more $\mathrm{P}$ and $\mathrm{Ca}$ in the bones than wild mountain ungulates. This difference is probably associated with the requirement for calcium during lactation and with a varying quality of diet during the winter period [30]. Domestic animals are fed during the winter and they need not suffer from nutrient deprivation. The primary reason for mineral deficiencies in grazing animals, (including phosphorus, calcium, sodium, cobalt, selenium and zinc) is a lack of plant-available minerals in soil [31]. Sivertsen et al. [32] reported evident interspecific differences between the amount of heavy metals found in the tissues of wild and domestic ruminants. Lead and aluminium levels were considerably higher in reindeer tissues compared to moose and sheep. Since a higher mobility of calcium is probably maintained in wild than domestic animals, lead may interfere with calcium metabolism to a greater extent in the wild as these animals may accumulate lead through ossification [33]. Reindeer generally took up more elements from atmospheric deposition than sheep. This was due to the high level of lichens in their diet [32]. Mosses and lichens are also a significant component of the winter diet of snow voles in Europe, and the amount of lead in the vole bones rapidly increased with age in winter. The increase did not continue in overwintered adults in summer and autumn [34]. Silver mountain vole (A. argentatus) is considered a keystone species in ecosystem succession and its presence is an indicator of the well-being of the ecosystem [35]. The species' diet consists mainly of small roots, leaves, seeds and flowers. According to the results of 80 stomachs examined from different seasons, silver mountain voles consume similar herbaceous food like narrow-headed voles. The species breeds from April to October and has a maximum of two to three litters. They sometimes consume animal food, e.g., Thysanoptera were found in their stomachs $[17,18]$. Snow voles also sometimes consume animal products, but in their stomachs mainly green remains of Poa and Taraxacum were found, which are also preferred by silver mountain voles and narrow-headed voles [35,36]. Narrow-headed vole (M. gregalis) also breeds from April to September, and lives in colonies up to $4000 \mathrm{~m}$ a.s.l. [17,18]. 
The food components and breeding behaviours constitutes suitable evidence to conclude that the silver mountain vole and the narrow-headed vole are ecologically equivalent rodent species to snow voles from European mountain ranges.

This study has shown that small rodents could be sampled to measure the bioavailability of lead to mammals in high mountain regions. Our results indicate that voles are suitable indicators of lead. This could be useful for ongoing monitoring or geographical studies, especially in fragile alpine habitats most likely to be affected by transboundary pollution.

\section{Conclusions}

The Tian-Shan mountains are less polluted by $\mathrm{Pb}$ than the West Carpathians, perhaps as a result of the longer history of industrialization in Western Europe as well as prevailing winds, which transport the atmospheric pollutants from the north-west parts of Europe toward the Tatra mountains. We can conclude that voles are very suitable indicators of the bioavailability of lead to mammals in high mountains and the silver mountain vole and the narrow-headed vole are ecologically equivalent rodent species to snow voles from European mountain ranges.

Acknowledgments: The present study has been funded by the European Structural Funds (ITMS, Project numbers: 26210120006 and 26110230078). For English language editing and proofreading, we are indebted to Amanda Clarahan. We are grateful to Zuzana Hrehová, L'udmila Janigová, Jaroslav Solár, Monika Suchá, and students of the Institute of High Mountain Biology for their help with sample collection.

Author Contributions: Zuzana Ballová gave comments and ideas on the research and was responsible for statistical and ecological analyses, interpretation of the results, and writing the manuscript. Marián Janiga gave basic ideas on the research and was responsible for field data collection, statistical and ecological analyses, interpretation of the results, and writing the manuscript.

Conflicts of Interest: The authors declare no conflict of interest. The funding sponsors had no role in the design of the study; in the collection, analyses, or interpretation of data; in the writing of the manuscript, and in the decision to publish the results.

\section{References}

1. Shotyk, W.; Le Roux, G. Biogeochemistry and cycling of lead. Met. Ions Biol. Syst. 2005, 43, 239-275. [PubMed]

2. Bing, H.; Wu, Y.; Zhou, J.; Ming, L.; Sun, S.; Li, X. Atmospheric deposition of lead in remote high mountain of eastern Tibetan Plateau, China. Atmos. Environ. 2014, 99, 425-435. [CrossRef]

3. Diaz, H.F.; Grosjean, M.; Graumlich, L. Climate variability and change in high elevation regions: Past, present and future. Clim. Chang. 2003, 59, 1-4. [CrossRef]

4. Grigholm, B.; Mayewski, P.A.; Aizen, V.; Kreutz, K.; Wake, C.P.; Aizen, E.; Kang, S.; Maasch, K.A.; Handley, M.J.; Sneed, S.B. Mid-twentieth century increases in anthropogenic $\mathrm{Pb}, \mathrm{Cd}$ and $\mathrm{Cu}$ in central Asia set in hemispheric perspective using Tien Shan ice core. Atmos. Environ. 2016, 131, 17-28. [CrossRef]

5. Zeng, H.; Wu, J.; Liu, W. Two-century sedimentary record of heavy metal pollution from lake Sayram: A deep mountain lake in central Tianshan, China. Quat. Int. 2014, 321, 125-131. [CrossRef]

6. Zhaoyong, Z.; Abuduwaili, J.; Fengqing, J. Heavy metal contamination, sources, and pollution assessment of surface water in the Tianshan mountains of China. Environ. Monit. Assess. 2015, 187, 33. [CrossRef] [PubMed]

7. Zhang, Z.; Abuduwaili, J.; Jiang, F. Determination of occurrence characteristics of heavy metals in soil and water environments in Tianshan mountains, central Asia. Anal. Lett. 2013, 46, 2122-2131. [CrossRef]

8. Wang, C.; Liu, Y.; Zhang, W.; Hong, S.; Hur, S.D.; Lee, K.; Pang, H.; Hou, S. High-resolution atmospheric cadmium record for ad 1776-2004 in a high-altitude ice core from the eastern Tien Shan, central Asia. Ann. Glaciol. 2016, 57, 265-272. [CrossRef]

9. Ciriaková, A.; Mursaliev, N.; Šoltés, R.; Lukáň, M.; Janiga, M. Lead concentrations in soils and plants of two altitudinal transects in the eastern Kyrgyz Tian Shan mountains-A preliminary study. Oecol. Mont. 2011, 20, 19-26.

10. Šefrna, L.; Previtali, F.; Comolli, R.; Cantelli, D.; Zdravkovic, M. Trace elements in soils in the northern and the central Tian-Shan (Kazakhstan-Kyrgyzstan). Geogr. Sb. České Geogr. Spol. 2008, 113, 253-268. 
11. Andasbayev, E.S.; Kenzhebekov, A.K.; Kanagatov, Z.Z. The ecological characteristic of the soil cover of middle mountains of the Zhongar-Alatau State National Nature Park (by the example of Nikonov Cordon). Oecol. Mont. 2013, 22, 38-40.

12. Janiga, M. Potential effects of global warming on atmospheric lead contamination in the mountains. In The Socio-Economic Causes and Consequences of Desertification in Central Asia; Behnke, R., Ed.; Springer: Dordrecht, The Netherlands, 2008; pp. 231-247.

13. Ashley, L.; Ershova, N. Climate change trends, impacts, and adaptation in Kara Kulja District, Southern Kyrgyzstan. Oecol. Mont. 2012, 21, 1-10.

14. Akbarov, K.A.; Nogay, A.Y.; Rajabov, A.B. Mountains and desertification, the social and economic reasons and consequences. Oecol. Mont. 2005, 14, 33-36.

15. Al Sayegh Petkovšek, S.; Kopušar, N.; Kryštufek, B. Small mammals as biomonitors of metal pollution: A case study in Slovenia. Environ. Monit. Assess. 2014, 186, 4261-4274. [CrossRef] [PubMed]

16. Smith, A.T.; Xie, Y.; Hoffmann, R.S.; Lunde, D.; MacKinnon, J.; Wilson, D.E.; Wozencraft, W.C.; Gemma, F. A Guide to the Mammals of China; Princeton University Press: Princeton, NJ, USA, 2010.

17. Yanuschevits, A.I.; Aizin, B.M.; Kydyraliev, A.K.; Umrikhina, G.C.; Fedyanina, T.F.; Shukurov, E.D.; Grebenyuk, R.V.; Tokobaev, M.M. Mammals of Kyrgyzstan; Ilim: Frunze, Kyrgyzstan, 1972.

18. Shukurov, E.D. Wild Mammals of Kyrgyzstan; Mektep: Frunze, Kyrgyzstan, 1989.

19. Batsaikhan, N.; Tsytsulina, K.; Formozov, N.; Sheftel, B. Microtus gregalis. (Errata Version Published in 2017). The IUCN Red List of Threatened Species 2016: e.T13431A115112748. Available online: http:/ /www. iucnredlist.org/details/13431/0 (accessed on 27 October 2017).

20. Molur, S. Alticola argentatus. (Errata Version Published in 2017) The IUCN Red List of Threatened Species 2016: e.T949A115054150. Available online: http://www.iucnredlist.org/details/949/0 (accessed on 27 October 2017).

21. Janiga, M.; Hrehová, Z.; Dimitrov, K.; Gerasimova, C.; Lovari, S. Lead levels in the bones of snow voles Chionomys nivalis (Martins, 1842) (Rodentia) from European mountains: A comparative study of populations from the Tatra (Slovakia), Vitosha and Rila (Bulgaria). Acta Zool. Bulg. 2016, 68, 291-295.

22. Gdula-Argasinska, J.; Appleton, J.; Sawicka-Kapusta, K.; Spence, B. Further investigation of the heavy metal content of the teeth of the bank vole as an exposure indicator of environmental pollution in Poland. Environ. Pollut. 2004, 131, 71-79. [CrossRef] [PubMed]

23. Janiga, M.; Chovancová, B.; Žemberyová, M.; Farkašovská, I. Bone Lead Concentration in Chamois Rupicapra Rupicapra Tatrica and Sources of Variation. In Proceedings of the 2nd World Conference Mountain Ungulates, Saint Vincent (Aosta), Italy, 5-7 May 1997; Parco Nazionale del Gran Paradiso: Aosta, Italy, 1998; pp. 145-150.

24. Hančinský, R. Comparison of the Selected Element Concentrations in the Bones of Wild Ruminants from West Carpathians and Tian-Shan Mountains; Žilina University: Žilina, Slovakia, 2014.

25. Aidaraliev, A.; Djeenbaeva, D.; Ormonbekov, T.; Shanazarov, A.; Aitmatov, I.; Akimaliev, D.A.; Mamatkanov, D.; Mirrahimov, M.; Otorbaev, K.; Toktomyshev, D. Mountains of Kyrgyzstan; National Center for Development of Mountain Regions of Kyrgzstan: Bishkek, Kyrgyzstan, 2002; p. 284.

26. Zhuang, P.; Zou, H.; Shu, W. Biotransfer of heavy metals along a soil-plant-insect-chicken food chain: Field study. J. Environ. Sci. 2009, 21, 849-853. [CrossRef]

27. Scheuhammer, A.M. Effects of acidification on the availability of toxic metals and calcium to wild birds and mammals. Environ. Pollut. 1991, 71, 329-375. [CrossRef]

28. Scheuhammer, A.M. Acidification-related changes in the biogeochemistry and ecotoxicology of mercury, cadmium, lead and aluminium: Overview. Environ. Pollut. 1991, 71, 87-90. [CrossRef]

29. Valašková, M.; Janiga, M. Metal contamination in vertebrates from the Tian-Shan mountains. Oecol. Mont. 2014, 23, 1-12.

30. Suttle, N.F. Mineral Nutrition of Livestock, 4th ed.; MPG Books Group: Bodmin, UK, 2010.

31. Alloway, B.J. Zinc in Soils and Crop Nutrition; International Zinc Association Brussels: Bruxelles, Belgium, 2004; pp. 1-16.

32. Sivertsen, T.; Daae, H.L.; Godal, A.; Sand, G. Ruminant uptake of nickel and other elements from industrial air pollution in the Norwegigan-Russian border area. Environ. Pollut. 1995, 90, 75-81. [CrossRef]

33. Minnema, D.J.; Michaelson, I.; Cooper, G. Calcium efflux and neurotransmitter release from rat hippocampal synaptosomes exposed to lead. Toxicol. Appl. Pharm. 1988, 92, 351-357. [CrossRef] 
34. Janiga, M.; Hrehová, Z.; Kostková-Zelinová, V. Seasonal effects of lead uptake by snow vole Chionomys nivalis (Martins, 1842) in West Tatra Mts.: Bone metal concentrations and hematological indices. Pol. J. Ecol. 2012, 60, 611-619.

35. Kumawat, M.M.; Singh, K.M.; Sen, D.; Tripathi, R.S. Threatened rodent species of Arunachal Pradesh. Int. J. Agric. Environ. Biotechnol. 2013, 6, 657. [CrossRef]

36. Metcheva, R.; Beltcheva, M.; Chassovnikarova, T. The snow vole (Chionomys nivalis) as an appropriate environmental bioindicator in alpine ecosystems. Sci. Total Environ. 2008, 391, 278-283. [CrossRef] [PubMed] 